\title{
A Coprological Survey of Gastrointestinal Parasites of Cattle in Udgir, Marathwada, India
}

\author{
M. K. Dappawar, B. S. Khillare, B. W. Narladkar and G. N. Bhangale* \\ Department of Veterinary Parasitology, College of Veterinary and Animal Sciences, \\ Kaulkhed Road, Udgir-413 517, Maharashtra, India \\ *Corresponding author
}

\section{A B S T R A C T}

\begin{tabular}{|l|}
\hline Ke y w or d s \\
$\begin{array}{l}\text { Coprological Survey, } \\
\text { Gastrointestinal Parasites, } \\
\text { Marathwada }\end{array}$ \\
\hline Article Info \\
\hline $\begin{array}{l}\text { Accepted: } \\
\text { 20 May } 2018 \\
\text { Available Online: } \\
\text { 10 June } 2018\end{array}$ \\
\hline
\end{tabular}

Keywords

Coprological Survey, Gastrointestinal Parasites,

Article Info

Accepted: Available Online:

\section{Introduction}

The gastrointestinal tract (GIT) of animals harbor wide variety of parasites like helminthes, coccidia etc. which cause clinical and sub clinical parasitism. Gastrointestinal parasites not only affect the health but also disturbs the feed intake, feed conversion and utilization as well as growth of the animal thereby severely affect the productive and reproductive performance of the animals which can be seen as loss in body weight, poor reproductive performance, digestive disturbance, emaciation for longer period and increased susceptibility of animals to other infections (Radostits et al., 1994; Yadav et al., 2004). In addition, there will be considerable economic losses due to morbidity and

\begin{abstract}
In a coprological survey of gastrointestinal parasites in cattle of Udgir and surrounding area was conducted during August 2015 to July 2016. The overall prevalence of gastrointestinal parasites in cattle was recorded to the extent of Strongyles sp. 9.30\%, Strongyloides sp. 3.40\%, Trichuris sp. $1.80 \%$, Moniezia expansa 0.70\%, Moniezia benedeni $0.20 \%$, Eimeria sp. $1.30 \%$, mixed infection $1.20 \%$ and Toxocara sp $0.70 \%$. In monsoon showed the highest infection of $30.27 \%$ while in winter $16.06 \%$ whereas declining trend with advancement of age the infection of parasites. Breed-wise analysis conducted for prevalence of gastrointestinal parasitic infection showed significant variation within the breeds of cattle present in the region.
\end{abstract}

mortality, predisposition to other diseases, loss in products such as meat, milk etc as well as those incurred on cost of drugs and veterinary aids. In spite of significant production losses, the problem is neglected due to its chronic and insidious nature. Therefore, the information on prevalence of gastrointestinal helminthes is always considered mandatory for evolving effective strategies for their management.

However the prevalence of gastrointestinal parasite infection in livestock exhibits differently with respect to the age sex breed of the animal, management practices, local climatic attributes such as temperature, rainfall, humidity, vegetation etc. and also the parasite species themselves. Therefore it is needed to estimate the possible variation in 
parasitic infection of each host species of animals in different geographic regions and which could help to design an effective control measures against economically important parasitic diseases. The present research work was planned with an objective to record the clinical and subclinical Gastrointestinal parasitic profile in cattle from Udgir region of Marathwada.

\section{Materials and Methods}

Location of study i.e. Udgir lies in the southern extreme of Marathwada region in Maharashtra state. The geographical location as per coordinates is $18^{\circ} 23^{\prime} 46^{\prime \prime} \mathrm{N} 77^{\circ} 07^{\prime} 03^{\prime \prime} \mathrm{E}$. Udgir's climate is classified as tropical. The area receives $977 \mathrm{~mm}$ average annual rainfall and is characterized by 40 to $80 \%$ range of humidity and range of temperature lowest being $12{ }^{\mathrm{E}} \mathrm{C}$ and highest being $40{ }^{\mathrm{E}} \mathrm{C}$.

Faecal samples from the cattle were collected throughout year during August 2015 to July 2016 comprising of all three seasons of the year from the TVCC of college, adopted villages, clinical camps and nearby Udgir area. These samples were processed in the laboratory by standard methods Flotation and Sedimentation techniques (Soulsby, 1982). Samples were examined under low and high power microscopic fields for presence of round worm eggs, tape worm proglottids, eggs of fluke and oocysts of enteroprotozoan. The eggs/oocysts so detected were further examined for morphology to know the specification of fluke eggs, tape worm, round worm and entero-protozoa. The data obtained were analyzed by Chi square test and conclusions presented accordingly.

\section{Results and Discussion}

During the period a total of 999 samples were included for the study and the overall prevalence of gastrointestinal parasites was found as $18.61 \%$ in cattle. The parasitic species wise prevalence is presented in Table 1. As regards season wise picture of parasite prevalence the per cent infection noted during the three seasons was $30.27 \%$ in monsoon, $18.61 \%$ in winter and $7.76 \%$ in summer Table $2)$. In summer least infection was recorded compared to monsoon and winter, while significantly higher infection was observed during rainy (monsoon) season.

Similar pattern of seasonal variation was observed for each individual parasitic species and species found as Toxocara sp, Strongyles sp., Strongyloides sp, Trichuris sp, Moniezia expansa, Moniezia benedeni, Eimeria sp, and mixed infections. In the present study mostly individual gastrointestinal parasitic infection as well as overall parasitic infections were reported as highest during monsoon, moderate during winter and lowest during summer in all host species. Similar pattern of seasonal variation was observed and reported by Sahoo et al., (2003), Pathak and Pal (2008), Shirale et al., (2008), Aktaruzzaman et al., (2013) and Laha et al., (2013).

The reasons for seasonal pattern experiencing highest prevalence of parasitic infections during monsoon season, slightly lower during winter and still lower or almost negligible during summer season could be due to various reasons. According to Soulsby (1966), the higher rainfall during monsoon season provides suitable molarity of salt which is important factor for ecdysis. It also helps in larval dispersion on pasture and increases the chances of contact between host and infective larvae. Stability of monsoon season for survival, development and dissemination of parasitic larvae and suitable environment for sporulation of Eimeria spp. oocysts. Devoid of optimum moisture and temperature for development of larvae in pasture during winter and summer might be the reason for lower infection. 


\section{Table.1 Species wise prevalence of gastrointestinal parasites}

\begin{tabular}{|c|c|c|}
\hline & Species & $\%$ prevalence \\
\hline 1 & Toxocara vitulorum & 0.70 \\
\hline 2 & Strongyloides sp & 3.40 \\
\hline 3 & Trichuris sp & 1.80 \\
\hline 4 & Moniezia expansa & 0.70 \\
\hline 5 & Moniezia benedini & 0.20 \\
\hline 6 & Eimeria sp & 1.30 \\
\hline 7 & Mixed infections & 1.20 \\
\hline \multirow[t]{7}{*}{8} & In Strongyle Group. & 9.30 \\
\hline & Trichostrongylus sp. & 31.8 \\
\hline & Bunostomum sp. & 17.2 \\
\hline & Mecistocirrus sp. & 16.7 \\
\hline & Haemonchus sp & 11.9 \\
\hline & Cooperia $s p$ & 8.9 \\
\hline & Overall Prevalence & 18.61 \\
\hline
\end{tabular}

Table.2 Season wise prevalence of gastrointestinal parasites in cattle at Udgir

\begin{tabular}{|l|c|c|c|}
\hline Season / Parasite & Summer & Monsoon & Winter \\
\hline Toxocara vitulorum & 0.32 & 0.83 & 0.90 \\
\hline Strongyles sp & 3.88 & 14.16 & 9.09 \\
\hline Strongyloides sp & 1.29 & 6.38 & 2.12 \\
\hline Trichuris sp & 0.64 & 3.61 & 0.90 \\
\hline Moniezia expansa & 0 & 1.66 & 0.30 \\
\hline Moniezia benedeni & 0 & 0.27 & 0.30 \\
\hline Eimeria sp & 0.64 & 1.66 & 1.51 \\
\hline Mixed infections & 0.97 & 1.66 & 0.90 \\
\hline Total number of animals examined & 309 & 360 & 330 \\
\hline Total positive and percentage & $* 7.76$ & $* 30.27$ & $* 16.06$ \\
\hline \multicolumn{2}{|c|}{$*$ Chi-square value 81.33} & $(1 \%-9.21,5 \%-5.99)$ & \\
\hline
\end{tabular}


Table.3 Age wise prevalence of gastrointestinal parasites in cattle at Udgir

\begin{tabular}{|c|c|c|c|c|c|c|}
\hline \multirow{2}{*}{$\begin{array}{l}\text { Age group } \\
\text { Parasite }\end{array}$} & \multicolumn{2}{|c|}{$\begin{array}{l}\text { Age group } 1^{\text {st }}(0-6 \\
\text { month) }\end{array}$} & \multicolumn{2}{|c|}{$\begin{array}{l}\text { Age group } 2^{\text {nd }}(6-18 \\
\text { month) }\end{array}$} & \multicolumn{2}{|c|}{$\begin{array}{l}\text { Age group } 3^{\text {rd }} \\
\text { (above } 18 \text { month) }\end{array}$} \\
\hline & Positive & $\%$ & Positive & $\%$ & Positive & $\%$ \\
\hline Toxocara vitulorum & 7 & 6.19 & 0 & 0 & 0 & 0 \\
\hline Strongyles $s p$ & 8 & 7.07 & 24 & 12.18 & 61 & 8.85 \\
\hline Strongyloides sp & 3 & 2.65 & 10 & 5.07 & 21 & 3.04 \\
\hline Trichuris sp & 1 & 0.88 & 3 & 1.52 & 14 & 2.03 \\
\hline Moniezia expansa & 7 & 6.19 & 0 & 0 & 0 & 0 \\
\hline Moniezia benedeni & 2 & 1.76 & 0 & 0 & 0 & 0 \\
\hline Eimeria sp & 3 & 2.65 & 2 & 1.01 & 8 & 1.16 \\
\hline Mixed infections & 5 & 4.42 & 3 & 1.52 & 4 & 0.58 \\
\hline$\%$ positive & 36 & $* 31.85$ & 42 & $* 21.31$ & 108 & $* 15.7$ \\
\hline $\begin{array}{l}\text { Total number of animals } \\
\text { examined }\end{array}$ & \multicolumn{2}{|c|}{113} & \multicolumn{2}{|c|}{197} & \multicolumn{2}{|c|}{689} \\
\hline
\end{tabular}

Table.4 Sex wise prevalence of gastrointetstinal parasites in cattle at Udgir (\%)

\begin{tabular}{|l|c|c|}
\hline Sex & Male & Female \\
\hline Toxocara vitulorum & 0.43 & 0.93 \\
\hline Strongyles sp & 10.10 & 8.61 \\
\hline Strongyloides sp & 4.30 & 2.62 \\
\hline Trichuris sp & 1.29 & 2.24 \\
\hline Moniezia expansa & 0.86 & 0.56 \\
\hline Moniezia benedeni & 0 & 0.37 \\
\hline Eimeria sp & 1.07 & 1.49 \\
\hline Mixed infections & 1.29 & 1.12 \\
\hline Total number of animals examined & 465 & 534 \\
\hline \% positive Chi-square value calculated was $0.24(1 \%-6.63,5 \%-3.84)$ & \\
\hline
\end{tabular}


Table.5 Breed wise prevalence of gastrointestinal parasites in cattle at Udgir (\%)

\begin{tabular}{|l|c|c|c|}
\hline \multicolumn{1}{|c|}{ Breed } & Non-Descript & Red Kandhari & Deoni \\
\hline Toxocara vitulorum & 0.95 & 0.88 & 0.27 \\
\hline Strongyles sp & 7.16 & 14.15 & 8.69 \\
\hline Strongyloides sp & 3.7 & 4.86 & 2.17 \\
\hline Trichuris sp & 2.71 & 1.76 & 0.81 \\
\hline Moniezia expansa & 0.24 & 1.32 & 0.81 \\
\hline Moniezia benedeni & 0.49 & 0 & 0 \\
\hline Eimeria sp & 0.98 & 0.44 & 2.17 \\
\hline Mixed infections & 1.23 & 0.44 & 1.63 \\
\hline Total number of animals examined & 405 & 226 & 368 \\
\hline \% positive Chi-square value calculated was 4.45 (1\% - 9.21, 5\% - 5.99) & $\mathbf{1 6 . 6}$ \\
\hline
\end{tabular}

The age wise parasite profile of the animals under study depicted Toxocara vitulorum, Moniezia expansa and Moniezia benedeni infection was highest in the calves (age group I), while Strongyles sp. and Strongyloides sp. were noted more in young adults (age group II), followed by in adults (age group III) and calves respectively (Table 3 ). Other parasitic species such as Trichuris sp., Eimeria sp. and quantum of mixed infections showed the less differences in three different age groups. Overall gastrointestinal parasitic infection in calves, young adults and adult were $31.85 \%$, $21.31 \%$ and $15.67 \%$ respectively. Mixed infections in the calves were found as higher as it were mostly contributed due to combination of Eimeria sp with helminthes. On the other side, mixed parasitic infections reported in young adults and adults was lower compared to calves. Statistically significant difference was noted in prevalence rates amongst three different age groups. Present results are in agreement with the reports of Pfukenyi et al., (2007) and Kabaka et al., (2013). The reason for higher prevalence in calves may be due to the susceptibility and first time exposure to the parasitic infections. It could also be due to non-adoption of recommended calf management. Contrary to present study observations, Akanda et al., (2014) noted higher parasitic infections in adults compared to young and weaners and it was ascertained to keeping adults for a longer period of time in breeding and milk production purposes or supply of inadequate feed against their high demand. Moreover, stress like lactation, pregnancy, nutritional deficiency which might be accounted for higher prevalence in adult cattle. While in another study Mathew et al., (2017) noted the prevalence of strongylosis irrespective of age groups.

In the present study, the overall prevalence of gastrointestinal infections in cattle didn't show any significant difference between two sexes, despite, in male cattle slightly higher prevalence $(19.35 \%)$ was recorded as compared to females (17.97\%). Mixed infections, like Toxocara sp and Trichuris sp were noted slightly higher in females as compared to males, while, other parasitic species Strongyles sp., Strongyloides sp, Moniezia expansa, Moniezia benedeni and Eimeria sp found slightly more in males in comparison to females (Table 4). In Udgir 
region males and females were taken for grazing to same pasture areas, having equal chances of acquiring the infections, which has been exactly reflected in the present study. Similar observation has been reported by Kemal and Teref (2013), who also narrated the similar reason that, an equal opportunity for infection when they were exposed to the parasites in the communal grazing pasture.

During the study, the faecal samples of three indigenous breeds i.e. Non-descript (ND), Red Kandhari (R.K) and Deoni were examined (Table 5). Among the indigenous breeds, Red Kandhari cattle showed the highest prevalence of gastrointestinal parasitic infections of $23.89 \%$, followed by Nondescript (17.53\%) and Deoni (16.57\%) cattle. As regards to individual parasite species, Strongyles sp. observed to be the most commonly infecting to all the breeds of host species and the infection percentage noted as $7.16 \%, 14.15 \%$ and 8.69 percent in ND, Red Kandhari and Deoni breeds of cattle, respectively. Strongyloides sp, Trichuris sp and Moniezia expansa showed little variation amongst the breeds studied. Mixed infections were found more in ND and Deoni than Red Kandhari cattle. However, statistically no significant differences were noted amongst the parasitic prevalence in these breeds. These differences may be attributed to the genetic makeup of the animals considering its role in susceptibility to the parasitic infection.

This study warrants the animal health machinery of the state to devise and implement a strategic plan to control the parasite infestations and maintain the livestock health and thereby production in this rainfed area.

\section{Acknowledgement}

The authors are thankful to the Associate Dean of College of Veterinary and Animal
Sciences, Udgir for providing necessary facilities to conduct this study.

\section{References}

Akanda, M. R.; Hasan, M. M. I.; Belal, S. A. ; Roy, A. C.; Ahmad, S. U. and Das, R. 2014. A Survey on Prevalence of Gastrointestinal Parasitic Infection in Cattle of Sylhet Division in Bangladesh. Am. J. Phytomed. Clin. Ther., 2(7): 855-860

Aktaruzzaman, M.; Rony, S. A.; Islam, M.A.; Yasin, M.G. and Rahman, A. K. M. 2013. Concurrent infection and seasonal distribution of gastrointestinal parasites in cross-bred cattle of Sirajganj district in Bangladesh. Vet. World, 6: 720-724

Kabaka, W. M.; Gitau, G. K.; Kitala, P. M.; Maingi, N. and Vanleeuwen, J. A. 2013. The prevalence of gastrointestinal nematode infection and their impact on cattle in Nakuru and Mukurweini districts of Kenya. Ethiop. Vet. J. 17(1): 95-104.

Kemal, J. and Terefe, Y. 2013. Prevalence of gastrointestinal parasitism of cattle in Gedebano Gutazer Wolene district, Ethiopia. J. Vet. Med. Anim. Health, 5(12): 365-370.

Laha, R.; Das, M. and Goswami, A. (2013) Gastrointestinal parasitic infections in organized cattle farms of Meghalaya. Vet. World, 6(2): 109-112.

Mathew Abraham, Pallippatt Thoomban Harshal, Karapparambu Gopalan Ajithkumar and Reghu Ravindran. 2017. Coprological Survey of Gastrointestinal Parasites of Dairy Cattle in Wayanad, Kerala, India. Int.J.Curr.Microbiol.App.Sci. $\quad 6(2)$ : 899-903.

Pathak, A. K. and Pal, S. (2008) Seasonal Prevalence of Gastrointestinal Parasites in Goats from Durg District 
of Chhattisgarh. Vet. World 1(5): 136-137

Pfukenyi, D.; Mukaratirwa, S.; Willingham, A. and Monrad, J. (2007) Epidemiological studies of parasitic gastrointestinal nematodes, cestodes and coccidia infections in cattle in the highveld and lowveld communal grazing areas of Zimbabwe. Onderstepoort J. Vet. Res.. 74(2): $129-142$

Radostits O.M., Blood D.C. and Gay C.C. 1994. Diseases caused by helminth parasites. In: Veterinary Medicine: A Textbook of Diseases of Cattle, Sheep, Pigs, Goats and Horses. 8th Edition. London, Balliere Tindall. Pp. 1223-1230.

Sahoo, N.; Mohanty, T. N and Ray, T. K. 2003. Seasonal incidence of gastrointestinal helminthic infection in cattle of Phulbani district, Orissa. Indian Vet. J., 80: 622-624.

Shirale, S. Y., Meshram, M. D. and Khillare, K. P. (2008) Prevalence of Gastrointestinal Parasites in Cattle of Western Vidarbha Region. Vet. World, 1(2): 45.

Soulsby, E.J.L. 1982. Helminthes, Arthropods and Protozoa of Domesticated Animals. Bailliere and Tindall, London; pp. 291-294

Soulsby. E.J.L. 1966. Biology of parasites. New York and London: Academic Press; pp. 185-196.

Yadav, A.; Khajuria, J. K.; Raina, A. K. 2004. Gastrointestinal parasitic infestation profile of bovines at R. S. Pura, Jammu. Journal of Veterinary Parasitology, 18(2): 167-169.

\section{How to cite this article:}

Dappawar M. K., B. S. Khillare, B. W. Narladkar and Bhangale G. N. 2018. A Coprological Survey of Gastrointestinal Parasites of Cattle in Udgir, Marathwada, India. Int.J.Curr.Microbiol.App.Sci. 7(06): 2851-2857. doi: https://doi.org/10.20546/ijcmas.2018.706.335 